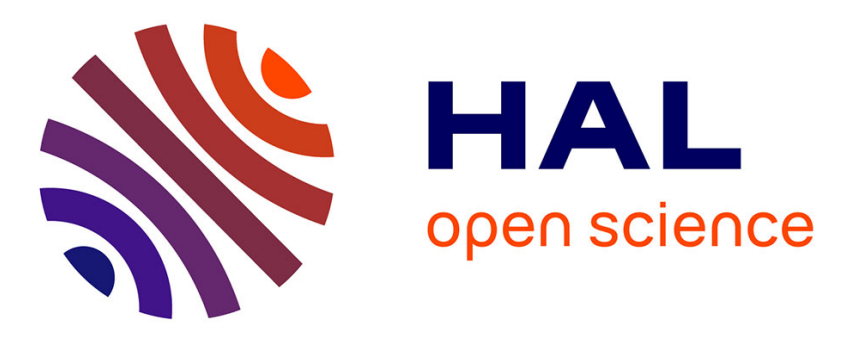

\title{
Strain partitioning and interplate friction in oblique subduction zones: Constraints provided by experimental modeling
}

\author{
A Chemenda, Serge Lallemand, A Bokun
}

\section{- To cite this version:}

A Chemenda, Serge Lallemand, A Bokun. Strain partitioning and interplate friction in oblique subduction zones: Constraints provided by experimental modeling. Journal of Geophysical Research, 2000, 105 (B3), pp.5567-5581. 10.1029/1999JB900332 . hal-01261396

\author{
HAL Id: hal-01261396 \\ https://hal.science/hal-01261396
}

Submitted on 25 Jan 2016

HAL is a multi-disciplinary open access archive for the deposit and dissemination of scientific research documents, whether they are published or not. The documents may come from teaching and research institutions in France or abroad, or from public or private research centers.
L'archive ouverte pluridisciplinaire $\mathbf{H A L}$, est destinée au dépôt et à la diffusion de documents scientifiques de niveau recherche, publiés ou non, émanant des établissements d'enseignement et de recherche français ou étrangers, des laboratoires publics ou privés. 


\title{
Strain partitioning and interplate friction in oblique subduction zones: Constraints provided by experimental modeling
}

\author{
A. Chemenda \\ Géosciences Azur, UMR 6526, Université de Nice-Sophia Antipolis et CNRS, Valbonne, France
}

\author{
S. Lallemand \\ Laboratoire de Géophysique, Tectonique et Sedimentologie, UMR 5573, \\ CNRS et Université Montpellier I, Montpellier, France
}

\author{
A. Bokun \\ Institute of Geology and Geochemistry of Fuel Minerals, Lvov, Ukraine
}

\begin{abstract}
Physical modeling of oblique subduction is performed to study the mechanism of strain partitioning. The model is two-layer and includes the elasto-plastic lithosphere (the overriding and subducting plates) and the low-viscosity liquid asthenosphere. The subduction is driven by a push force from a piston and a pull force when the density contrast $\Delta \rho$ between the subducting plate and the asthenosphere is positive. We vary both $\Delta \rho$ and the interplate friction (frictional stresses). Slip partitioning is obtained only in the models with high interplate friction and only when the overriding plate contains a weak zone. This zone in the models corresponds either to locally thinned lithosphere or to cut (fault). The horizontal, trench-normal component of the interplate friction force $\left|F_{\mathrm{fh}}\right|$ can be comparable with the absolute value of the horizontal component of the nonhydrostatic interplate pressure force $\left|F_{\mathrm{p}_{\mathrm{h}}}\right|$ in the subduction zone. $F_{\mathrm{f}_{\mathrm{h}}}$ is always negative (compression), while $F_{\mathrm{p}_{\mathrm{h}}}$ can be either negative (compressional subduction regime) or positive (extensional regime). High friction, which promotes partitioning, can completely cancel the extensional (suction) force $F_{\mathrm{ph}_{\mathrm{h}}}$. Back arc tension and strike-slip faulting appear thus as conflicting processes, although they can coexist in the same subduction zone, depending on the relative values of relevant forces. It appears that high friction can exist only in compressional subduction zones where partitioning should develop more easily. This conclusion is supported by the comparison of two oblique subduction zones, having similar geometry: the compressional southern Kurile zone (strong partitioning) and extensional southern Ryukyu zone (no lithospheric-scale partitioning). Other factors controlling the strain partitioning are the length of the oblique subduction zone, the boundary conditions at the transverse limits of the forearc sliver, and of course, the obliquity of subduction.
\end{abstract}

\section{Introduction}

Strain partitioning in subduction zones consists of the accommodation of oblique plate convergence by two processes: subduction with lesser obliquity and along-trench translation of the frontal wedge of the overriding plate, the forearc sliver. The along-trench displacement is accompanied by the strike-slip motion along one or several faults within the overriding plate (Figure 1). Theoretically, the total strike-slip component should be proportional to the subduction obliquity angle $\phi[$ Fitch, 1972] defined in Figure 1 but certainly depends on other factors as well because there are regions with oblique subduction where no transcurrent faulting is observed (Marianas, for example). What

Copyright 2000 by the American Geophysical Union.

Paper number 1999JB900332.

0148-0227/00/1999JB900332\$09.00 these factors are and how they influence the partitioning is a subject of discussion in numerous papers [Jarrard, 1986a; McCaffrey, 1992; Liu et al., 1995; Lallemand, 1999]. Different authors propose various, sometimes controversial, explanations of this phenomenon. For example, Fitch [1972], Beck [1983], and Jarrard [1986a] suggest that the partitioning occurs when the interplate coupling is strong, while Yu et al. [1993] and Liu et al. [1995] reach the opposite conclusion. Liu et al. [1995] emphasize the key role of the slab-pull force. Almost all authors agree that the interplate coupling is a basic factor controlling the partitioning, although this notion does not have a clear physical definition; different "couplings " have been introduced: a "general" coupling [Uyeda and Kanamori, 1979], a seismic coupling [Ruff, 1989], a mechanical coupling [Platt, 1993], and a kinematic coupling [McCaffrey, 1992].

Two principal types of observations are used to estimate the partitioning. The first one refers to the study of the transcurrent faults cutting the overriding plate [Beck, 1991; Wesnousky and Jones, 1994]. Displacement along these trench-parallel faults is a 


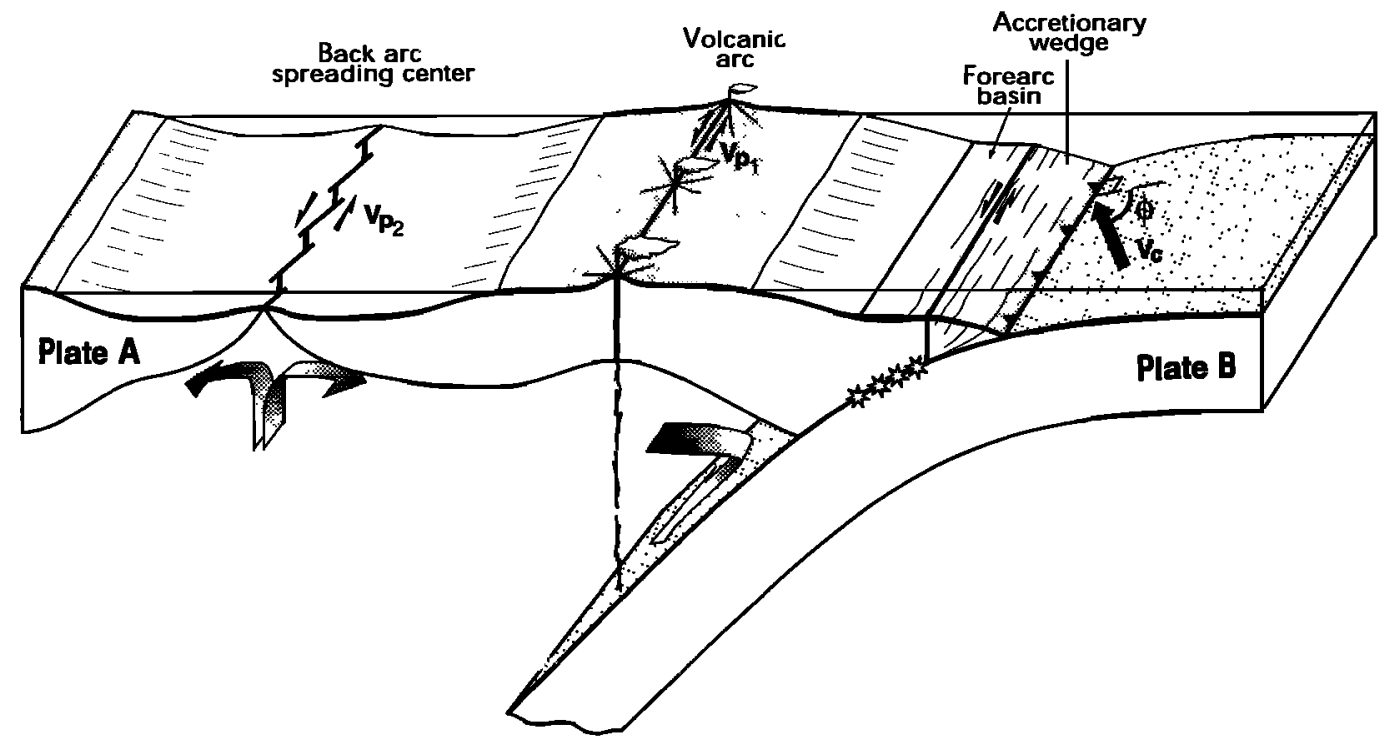

Figure 1. General scheme of slip partitioning. $V_{c}$ is the convergence velocity vector between plates $A$ and $B ; V_{p_{1}}$ and $V_{p_{2}}$ are the slip velocity components along the volcanic arc and back arc spreading axis, respectively; $\phi$ is the convergence obliquity angle. Stars indicate the zone of strong seismic coupling.

direct confirmation of strain partitioning. The degree of partitioning can be defined as $p_{k}=V_{p} /\left(V_{c} \sin \phi\right)$, where $V_{p}$ is the rate of along-trench translation of the forearc sliver, $V_{c}$ is the convergence rate, and $\phi$ is the convergence obliquity angle (see Figure 1). Large-scale active shear faults are normally located along weak zones associated with the volcanic arc (e.g. the Kurile arc), with preexisting fault or suture zones in the forearc area (Sumatra) or with both (Philippines, Sumatra, Kurile, North Island, New Zealand, Aleutians) [Kimura, 1986; Ryan and Coleman, 1992; Diament et al., 1992]. Transcurrent motion of the arc plate can also be accommodated through oblique spreading in backarc basins (the Andaman Sea [Curray et al., 1979] and Commander Sea [Baranov et al., 1991]). Smaller-scale, sometimes diffuse, strike-slip faulting has also been observed in accretionary wedges of the southern Kermadec [Collot and Davy, 1998], Hikurangi [Barnes and Mercier de Lepinay, 1997], and southern Ryukyu arcs [Lallemand et al., 1999].

Another type of observation, used to reveal and quantify strain partitioning, is the deflection angle $\gamma$ of the interplate seismic slip vector $V_{s}$ from the convergence vector $V_{c}$ [McCaffrey, 1992; $Y u$ et al., 1993]. A degree of partitioning $p_{s}$ is defined in this case as $p_{\mathrm{s}}=1-(\phi-\gamma) / \phi ; p_{\mathrm{s}}=0$ corresponds to zero partitioning, and $p_{\mathrm{s}}=$ 1 corresponds to complete partitioning. Logically, kinematic $p_{\mathrm{k}}$ and seismic $p_{\mathrm{s}}$ criteria should be direstly related and proportional. However, this is not always the case, and the use of the slip vector criterion leads sometimes to controversial conclusions. For example, in Tonga, $p_{s}>1$ [ $Y u$ et al., 1993], which is inconsistent with the traditional assumption that convergence vector splits into two components; one oriented between this vector and trench normal and the other parallel to the trench. In other subduction zones (Kamchatka, Ryukyu, or northern Japan), $p_{\mathrm{s}}<0$, which could be interpreted as transcurrent motion of the forearc sliver in a direction opposite to that predicted by strain partitioning model [Liu et al., 1995]. Value of $p_{\mathrm{s}}$ can also lead one to assume a very high partitioning in subduction zones where no strike-slip faults have been revealed at all (the Marianas, for example).

Certainly, there are other factors controlling the $p_{s}$ value besides the transcurrent displacement of the forearc sliver. One of them follows from the fact that in the traditional approach the plates in subduction zones are considered to be rigid, while in reality, they undergo intense internal strain. Subducting lithosphere bends under the overriding plate; this bending accelerates relative sliding of the plates along the interplate surface in the direction perpendicular to the trench. The overriding plate also undergoes deformation not of the strike-slip type. This plate can exhibit shortening or extending in the back arc to forearc area to a degree which is often underestimated. Recent Global Positioning System (GPS) measurements show, for example, that the northern part of the Lau Basin is opening at a rate of about $16 \mathrm{~cm} / \mathrm{yr}$ [Bevis et al. 1995]. The corresponding subduction rate thercfore eache. $2 \%$ $\mathrm{cm} / \mathrm{yr}$ instead of the $8 \mathrm{~cm} / \mathrm{yr}$ predicted by NUVEL-1 model [ $D e$ Mets et al., 1990]. The opening rate of the southern Okinawa Trough was also neglected in earlier kinematic models [Seno et al., 1993], which resulted in underestimation of the subduction rate in the southern Ryukyu by 3-4 cm/yr [Imanishi et al., 1996; Lallemand et al., 1999]. Not only does the magnitude of the convergence vector have to be corrected, but its orientation has to be corrected as well.

Considering the above remarks, it may be assumed that there is only one reliable criterion to define strain partitioning in a subduction zone: the along-trench displacement of the forearc sliver. Such a displacement can be accommodated along active, transcurrent lithospheric-scale faults within the overriding plate and/or along the back arc spreading center.

From the mechanical point of view, the partitioning represents a three-dimensional (3-D) problem. In the present paper we address this problem based on the results from 3-D experimental modeling of oblique subduction. Both mathematical [Platt, 1993; Braun and Beaumont, 1995] and experimental [Pinet and Cobbold, 1992; Burbidge and Braun, 1998] modeling have been already performed to study strain partitioning. Usually, only deformation of the overriding plate with some "rigid" boundary conditions along the interplate surface or the lithosphere (crust) base has been modeled. We model the whole subduction process, varying the subduction parameters in order to understand a firstorder lithospheric-scale mechanics of the partitioning. 


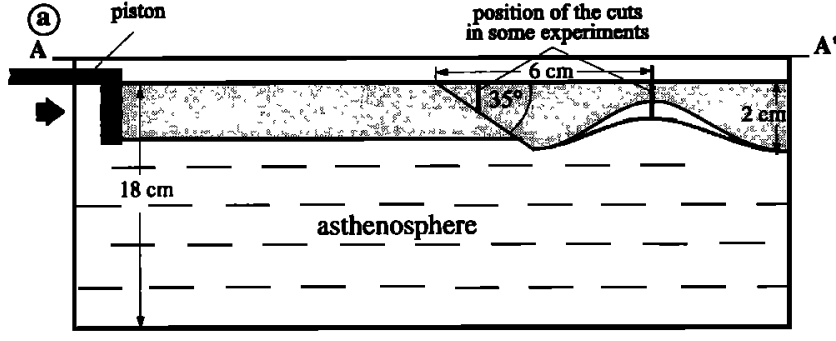

(b)

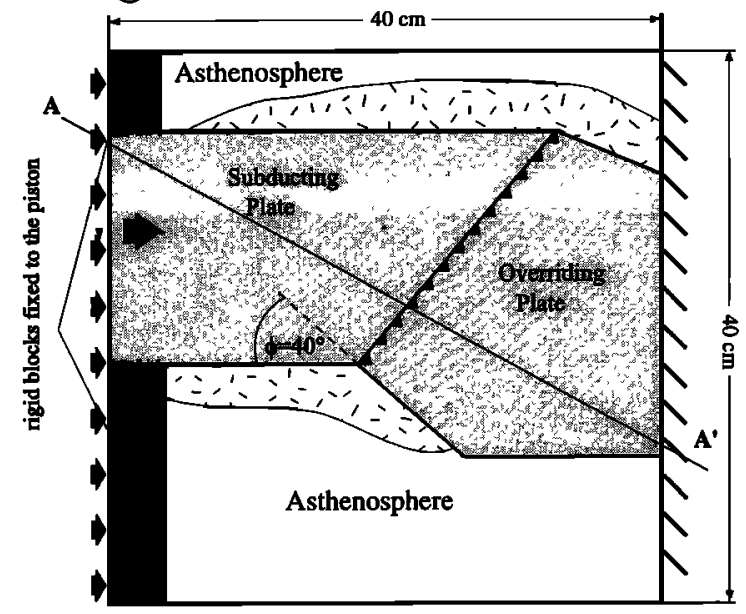

Figure 2. Scheme of the experiments. (a) Cross section and (b) view from above. The thick shaded lines in Figure 2a correspond to the experiments with vertical cuts. The patterned areas at the two sides of the "lithosphere" in Figure $2 b$ correspond to a 1$\mathrm{mm}$-thick layer of weak plastic material floating at the surface of the "asthenosphere." This layer, welded to the lithosphere, has density $0.86 \times 10^{3} \mathrm{~kg} / \mathrm{m}^{3}$ and yield limit, $\sim 3 \mathrm{~Pa}$. It serves to prevent the liquid asthenosphere (water) from penetration onto the surface of the lithosphere during subduction (formation of the trench of about 1-mm depth).

\section{Experimental Set-up and Similarity Criteria}

The scheme of the experiments is presented in Figure 2. Both the overriding and subducting plates are one layer and are made of compositional systems consisting of alloys of solid hydrocarbons, mineral oils, finely grounded powders, and small quantities of surface-active substances. The rheologic properties of these materials are strongly temperature-dependent. The experiments are conducted at a temperature of around $40^{\circ} \mathrm{C}$ at which the materials possess elasto-plastic properties with about $50 \%$ strain weakening. The values of the rherologic parameters ar this tem- perature are given in Table 1 . The composition, physicochemical, and rheologic properties of these materials are described in detail by Shemenda [1992, 1994].

In all experiments the overriding plate is thinned from below to simulate a weak zone associated with the volcanic arc. Such a thinning to about $30 \mathrm{~km}$ has been clearly revealed in some real arcs [Zhao et al., 1994] and follows from thermal [Furukawa, 1993] and petrological [Schmidt and Poli, 1998] models of subduction zones. A thinning and weakening of the plate in the arc area can be caused by a number of factors such as induced convection in the mantle and magmatic activity (presence of magma chambers, and channels).

The lithosphere is underlain by a low-viscosity asthenosphere, which is pure water in the model. The viscous interaction between the lithosphere and the asthenosphere is thus neglected. A justification for such a simplification is that the tangential stress at the lithospheric base is -2 orders of magnitude lower than the lithosphere effective strength due to low viscosity of the asthenosphere [Turcotte and Schubert, 1982]. Therefore strain partitioning (deformation of the overriding plate) is mainly defined by the stress conditions along the interplate surface. The mantle/lithosphere viscous interaction becomes more important with depth. The subduction can be either facilitated or resisted by this interaction, which corresponds to increase or decrease, respectively, in the effective pull force that controls the interaction between the plates in subduction zone. The pull force $F_{p l}$ is varied in the experiments and along with the push force produced by a piston drives subduction. The pull force $F_{\mathrm{p} 1}$ is proportional to the density contrast between the subducting lithosphere $\rho_{l}$ and the asthenosphere $\rho_{a}$. The $\rho_{a}$ value is the same in all experiments, while $\rho_{l}$ is either equal to or slightly higher than $\rho_{\mathrm{a}}$. The density of the overriding plate is always equal to that of the asthenosphere. The yield limit $\sigma_{s}$ of both plates is the same. Two values of the interplate friction have been tested: one was reduced almost to zero using lubricators, another was high. To increase the friction we have used a special adhesive material which was spread on the surface of the subducting plate and on the internal (contact) surface of the overriding wedge. The interplate friction was thus equal to the adhesion or shear yield limit of this material which is $\sim 2 \mathrm{~Pa}$. The initial subduction angle $\beta=35^{\circ}$ (Figure 1a) changes during subduction and is $\sim 18^{\circ}$ at shallow depth and $\sim 40^{\circ}$ near the overriding plate base which approximates the average dip of Benioff zones from 0 to 100-km depth [Jarrard, 1986b].

The similarity criteria which are met in this modeling are as follows [Shemenda, 1994]:

$$
\begin{gathered}
\sigma_{S} /\left(\rho_{1} g H\right)=\text { const } \rho_{/} / \rho_{\mathrm{a}}=\text { const; } \tau_{\mathrm{D}} / \sigma_{\mathrm{s}}=\text { const; } \\
\phi=\text { const; } V_{\mathrm{c}} t / H=\text { const. }
\end{gathered}
$$

Here $\sigma_{\mathrm{s}}$ is the yield limit of the lithosphere under normal load; $p_{l}$ and $\rho_{a}$ are the densities of the lithosphere and the asthenosphere,

Table 1. Parameter Values for the Model and Prototype

\begin{tabular}{lcccccccc}
\hline & $\sigma_{\mathrm{s}}, \mathrm{Pa}$ & $H, \mathrm{~m}$ & $\begin{array}{c}\rho_{l}, 10^{3} \\
\mathrm{~kg} / \mathrm{m}^{3}\end{array}$ & $\begin{array}{c}\rho_{\mathrm{a}, 10^{3}} \\
\mathrm{~kg} / \mathrm{m}^{3}\end{array}$ & $\tau_{\mathrm{n}} ; \mathrm{Pa}$ & $\phi$ & $V$ & $t$ \\
\hline Model & 24 & $2 \times 10^{-2}$ & $\begin{array}{c}1 \\
(1.03)\end{array}$ & 1 & 2 & $40^{\circ}$ & $10^{-4} \mathrm{~m} / \mathrm{s}$ & $1 \mathrm{~min}$ \\
Prototype & $2.4 \times 10^{8}$ & $6 \times 10^{4}$ & $\begin{array}{c}3.3 \\
(3.4)\end{array}$ & 3.3 & $2 \times 10^{7}$ & $40^{\circ}$ & $10 \mathrm{~cm} / \mathrm{yr}$ & $1.8 \mathrm{Ma}$ \\
\hline
\end{tabular}

The $\sigma_{\mathrm{s}}$ is the yield limit for the lithosphere under normal load; $\rho_{l}$ and $\rho_{\mathrm{a}}$ are the densities of the lithosphere and the asthenosphere; $\tau_{n}$ is the interplate friction stress; $\phi$ is the subduction obliquity angle; $H$ is the average thickness of the lithosphere; $V$ is the rate of plate convergence; and $t$ is the time. 

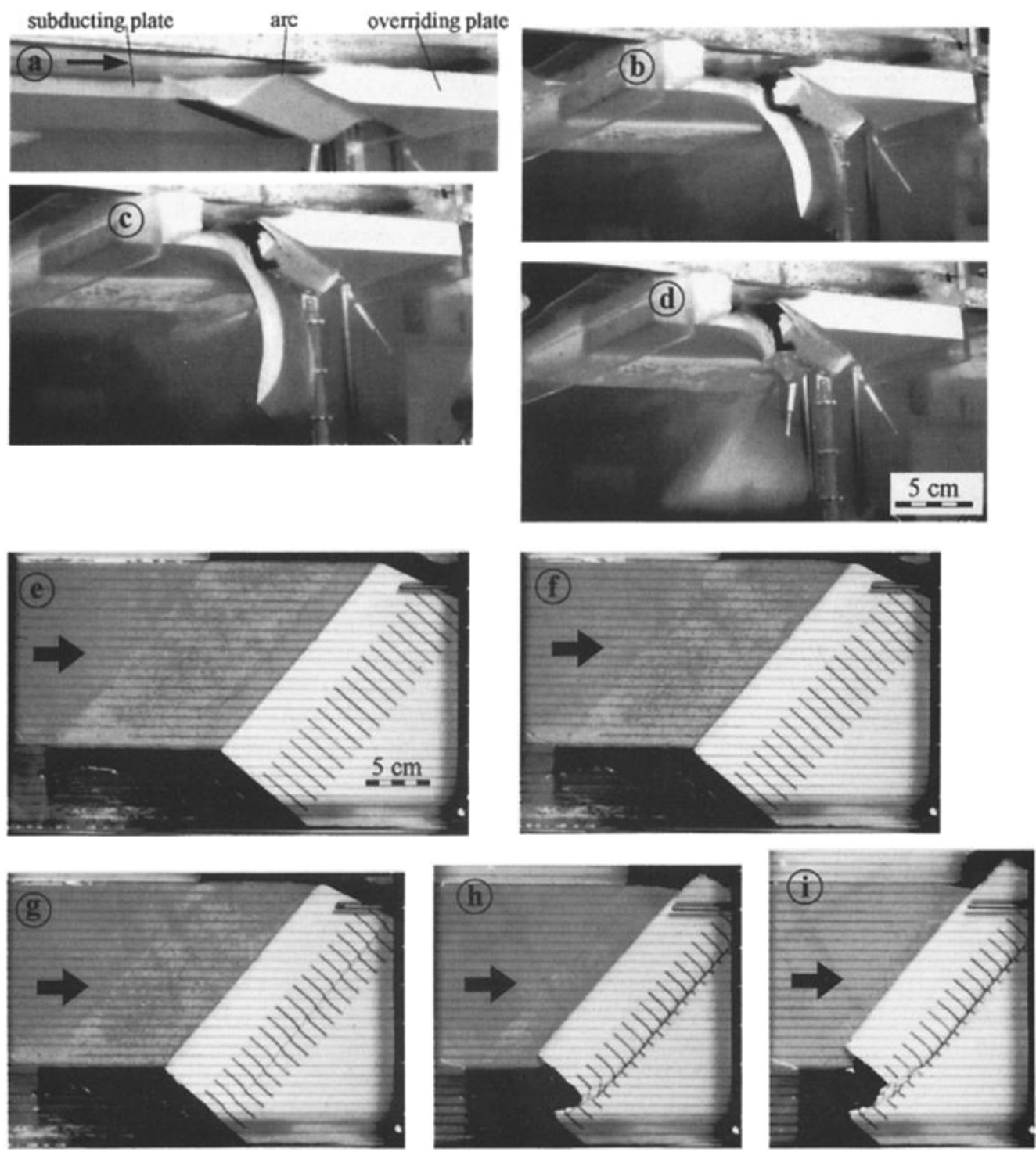

Figure 3. Experiment 1 (photographs of the successive stages of the experiment): high interplate friction, dense subducting plate, the overriding plate is thinned in the arc area (see Tables 1 and 2). (a) to (d), view of the model from the side; (e) to (i), view from above. Here and on the following figures, the photographs taken in cross section and in plan view are not synchronous, and the scales in cross section and in plan are not equal.

Table 2. Conditions and Results From the Experiments

\begin{tabular}{lcccccc}
\hline Experiment & $\begin{array}{c}\text { Interplate } \\
\text { Friction }\end{array}$ & $\rho_{l}-\rho_{\mathrm{a}}$ & $\begin{array}{c}\text { Upper Plate } \\
\text { Weakening }\end{array}$ & $\begin{array}{c}\text { Type of } \\
\text { Failure }\end{array}$ & $\begin{array}{c}\text { Degree of Parti- } \\
\text { tioning } p \mathrm{k}\end{array}$ & $\begin{array}{c}h \\
(\mathrm{~mm})\end{array}$ \\
\hline N1 (Figure 3) & High & $>0$ & arc-notch & arc thrust & $0.63-0.70$ & 5 \\
N2 (Figure 4) & low & $>0$ & arc-notch & no failure & 0 & 5 \\
N3 (Figure 5) & high & $>0$ & arc-cut & cut & $0.87-1$ & 15 \\
N4 & high & 0 & arc-cut & cut & $0.9-1$ & 15 \\
N5 (Figure 6) & high & $>0$ & Forearc-cut & cut & $0.46-0.75$ & 15 \\
N6 (Figure 7) & low & 0 & arc-notch & arc thrust & 0 & 5 \\
N7 (Figure 8) & low & 0 & arc-notch & opposite & 0 & 5 \\
& & & & arc thrusts & & \\
\hline
\end{tabular}

See Figure 2 for explanation; $h$ is the thickness of the overriding plate in the arc area. Degree of partitioning is defined as $p_{k}$ $=V \mathrm{p} /\left(V_{\mathrm{c}} \sin \phi\right)$, where $V_{\mathrm{p}}$ is the displacement rate along the transcurrent fault in the arc/forearc area; $V_{\mathrm{c}}$ is the convergence rate, and $\phi$ is the subduction obliquity angle. 
respectively; $\tau_{\mathrm{n}}$ is the interplate friction stress; $\phi$ is the subduction obliquity angle; $H$ is the average thickness of the lithosphere; $g$ is the acceleration of gravity; $V_{c}$ is the rate of plate convergence; and $t$ is time. The parameter values adopted for the prototype and the model which satisfy the conditions (1) are presented in Table 1. For more details regarding the properties of the model materials, experimental procedure, and scaling, see Shemenda [1992, 1994], who describes similar experiments on orthogonal subduction.

\section{Results of the Experiments}

A total of 40 experiments have been conducted under different conditions. In this paper we describe seven representative experiments (see Tables 1 and 2 ) and summarize the results from the others.

\subsection{Experiment 1}

The interplate friction in this experiment is high. The density of the subducting plate is larger than that of the asthenosphere. The overriding plate has a notch (see Figure $2 \mathrm{a}$ and Table 2), corresponding to the volcanic arc area, but is continuous. The thinning of this plate was increased progressively from one experiment to another conducted under the same conditions until the plate failed in the weak zone during subduction. The obtained limit thickness value is $h=5 \mathrm{~mm}$ ( $25 \%$ of "normal" lithospheric thickness), which corresponds to experiment presented in Figure 3. During subduction the thinned area in the overriding plate undergoes plastic dextral shear (see bending of the markers on Figures $3 \mathrm{f}$ and $3 \mathrm{~g}$ ) and then fails along a trenchward dipping reverse fault (backthrust) with strike-slip component (Figures $3 \mathrm{~g}$ and $3 \mathrm{~h}$ ). The failure is followed by slip partitioning. The plate convergence is now accommodated by less oblique subduction in the main subduction zone, and by thrusting and dextral strike-slip motion along the arc. At the stage in Figure $3 \mathrm{~h}$, the total amount of convergence is $5.4 \mathrm{~cm}$, the underthrusting in the arc fault reaches $1.5 \mathrm{~cm}$, and the shear displacement along this fault is 2.7 $\mathrm{cm}$. The underthrusting within the arc then stops, while along-arc displacement of the forearc block continues. A degree of partitioning $p_{\mathrm{k}}$ (see definition in Table 2) of $\sim 0.65$ remains constant from the nucleation of the arc fault to the end of the experiment. At the last stages of the experiment the horizontal normal stress within the overriding plate is close to zero. As the subducting plate is denser than the asthenosphere, the subducted slab finally breaks off (Figure 3d).

\subsection{Experiment 2}

The difference of this experiment (Figure 4) from experiment 1 is that now the interplate friction is very low. At the last stages the overriding plate is under trench-normal tension which is, however insufficient to fail the plate. There is no partitioning.

\subsection{Experiment 3}

In this experiment (Figure 5) the interplate friction is high, and the subducting plate is denser than the asthenosphere. The over- riding plate is vertically cut along the axis of the "arc." The lithosphere thickness in the arc is increased to $15 \mathrm{~mm}$ (compared to 5 $\mathrm{mm}$ in the previous experiments) to avoid the formation of the arc thrust. The friction along the cut is very low. Almost complete $(\sim 0.9)$ partitioning is observed in this experiment from the very beginning: the forearc block moves along the trench with the rate almost equal to $V_{c} \sin \phi$. At the initial stages of subduction the overriding plate is under compression which reduces during experiment to near zero.

\subsection{Experiment 4}

The densities of the subducting plate and the asthenosphere are equal. The rest of the parameters are the same as in experiment 3. The result (kinematics) is the same, but the overriding plate is under constant compression during experiment which is $\sim 2$ times greater than during the initial stages of experiment 3 .

\subsection{Experiment 5}

The conditions of this experiment (Figure 6) are the same as of experiment 3 ; the only difference is that the vertical cut is made in the forearc at a distance of $1 \mathrm{~cm}$ (corresponding to $\sim 30 \mathrm{~km}$ in nature) from the trench. At the beginning of the experiment the degree of slip partitioning is near 0.75 . The shifting, very narrow forearc sliver intrudes the weak material which surrounds the lithosphere (see Figure $2 \mathrm{~b}$ ) and causes some resistance to the sliver motion. At the same time, the interplate friction force decreases during the partitioning because the length of the sliver, which is in contact with the subducting plate, becomes smaller. These two factors cause the degree of partitioning to reduce to $\sim 0.5$ during later stages of the experiment.
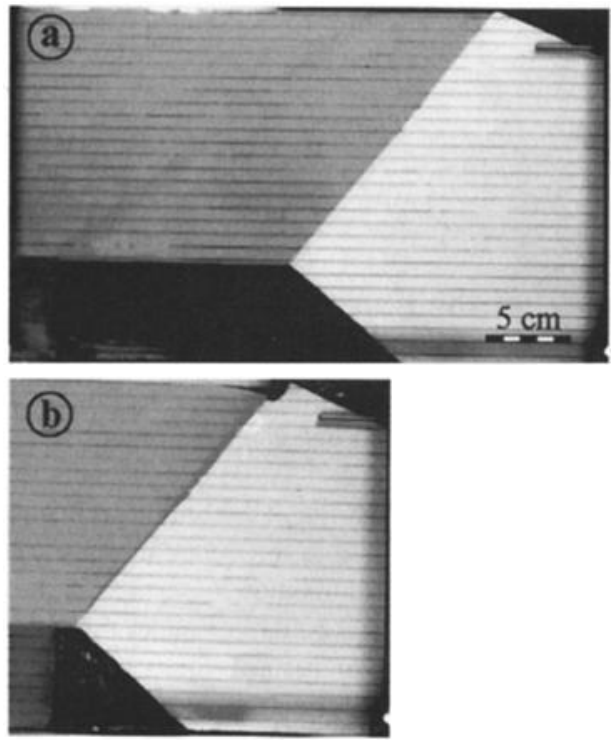

Figure 4. Experiment 2. View from above of initial (a) and final (b) stages of the experiment. Low friction, dense subducting plate (see Tables 1 and 2). 

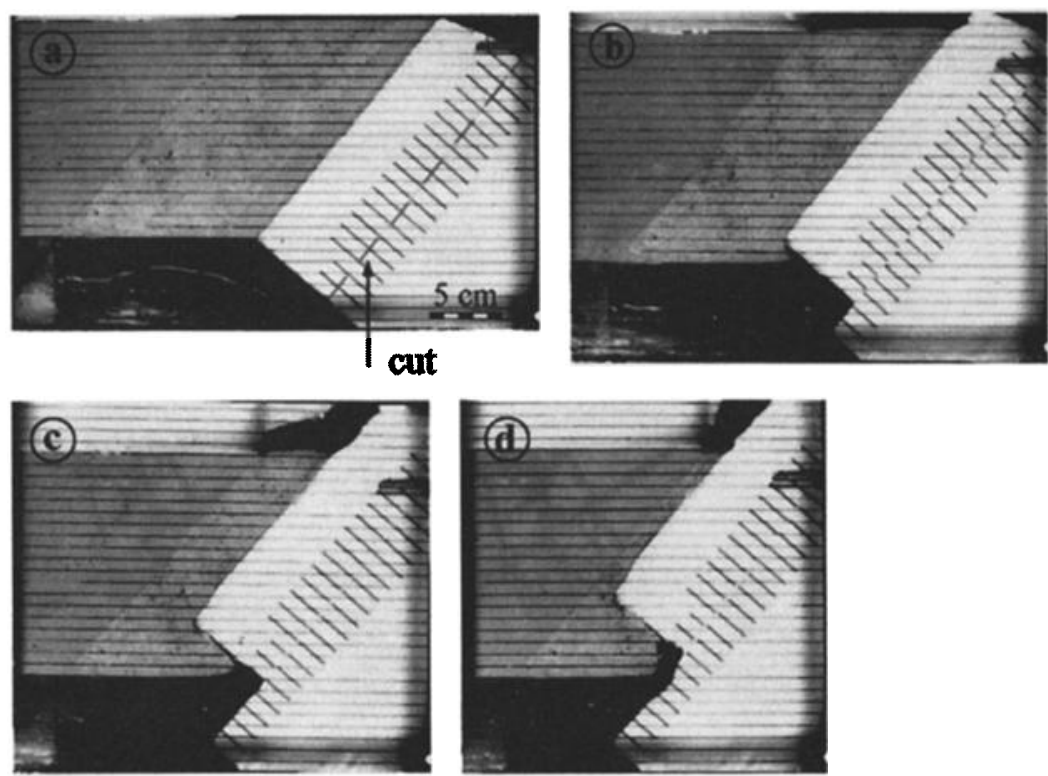

Figure 5. Experiment 3: view from above of four experimental stages. High friction, dense subducting plate, the overriding plate is vertically cut in the arc area (see Tables 1 and 2).

\subsection{Experiment 6}

The interplate friction is low, the densities of the subducting plate and the asthenosphere are the same, the overriding plate is continuous and is thinned in the arc to $5 \mathrm{~mm}$. During subduction, the overriding plate fails in the arc area along a fault dipping trenchward (backthrust), but there is no partitioning at all (Figure 7).

\subsection{Experiment 7}

The conditions are the same as in experiment 6, but the overriding plate fails in a more complex way: there are two faults dipping in opposite direction at different segments of the arc (Figure 8). No partitioning has been observed.

\section{Analysis of the Experimental Results}

The first direct conclusion following from the presented experiments is that partitioning occurs only if the interplate friction stress $\tau_{n}$ is high (experiments $1,3,4$, and 5 ). This result has a simple mechanical explanation. The only force enabling the forearc sliver to move parallel to the trench in our experiments is the friction force which is defined as $F=S \tau_{n}$ ( $S$ is the square of the interplate surface). Below we will consider this force per unit length of the plate boundary defined $F_{\mathrm{f}}=F / l$, where $l$ is the length of the plate boundary (Figure 9 ). $F_{\mathrm{f}}$ has three components: along-trench component $F_{\mathrm{f}_{\mathrm{f}}}$, vertical component $F_{\mathrm{f}}$, and horizontal, perpendicular to the trench component $F_{f_{\mathrm{h}}}$. They can be expressed in terms of the obliquity $\phi$ and the subduction $\beta$ angles (Figure 9) as

$$
\begin{aligned}
& F_{\mathrm{f}_{\mathrm{t}}}=F_{\mathrm{f}} \sin \phi ; \\
& F_{\mathrm{f}_{\mathrm{v}}}=F_{\mathrm{f}} \cos \phi \sin \beta ; \\
& F_{\mathrm{f}_{\mathrm{h}}}=-F_{\mathrm{f}} \cos \phi \cos \beta
\end{aligned}
$$

(here and below, the horizontal force oriented toward the overriding plate is assumed to be negative). Along-trench translation of the forearc sliver is caused by the along-trench component of the friction force $F_{\mathrm{f}_{\mathrm{f}}}$. The static equilibrium condition for the sliver is

$$
F_{\mathrm{f}_{\mathrm{t}}}=F_{\mathrm{a}}+F_{\mathrm{d}} l+F_{\mathrm{d}} l l,
$$

where $F_{\mathrm{a}}$ is the force per unit length resisting the shear along the strike-slip fault and $F_{\mathrm{c}}$ and $F_{\mathrm{e}}$ are the boundary forces resisting the partitioning which are defined in Figure 9. In the conducted experiments, $F_{\mathrm{c}}=F_{\mathrm{e}} \approx 0$. Therefore the condition for the partitioning in the experiments is reduced to

$$
F_{\mathrm{ft}}=F_{\mathrm{a}}
$$

A trivial consequence from the first equation in (2) is that the increase in the obliquity angle $\phi$ promotes the partitioning. In the experiments with vertical lubricated cuts in the arc and forearc (experiments 3,4 , and 5 ), $F_{\mathrm{a}}$ is very small; therefore the degree of partitioning is very high. In experiments 1 and 5 , where strikeslip motion occurs along the nonlubricated faults forming during the experiment, $F_{\mathrm{a}}$ is higher; therefore the degree of partitioning is lower (see Table 2 )

The horizontal compressive force $F_{\mathrm{h}}$ exerted on the overriding plate per unit length perpendicular to the trench is

$$
F_{\mathrm{h}}=F_{\mathrm{fh}} \text {, }
$$

which is true only when the friction force is the only force acting in the subduction zone and totally controls the interaction between the plates. In fact, along with the tangential (frictional) stress $\tau_{\mathrm{n}}$, this interaction is defined also by the normal stress $P_{\mathrm{n}}$, 

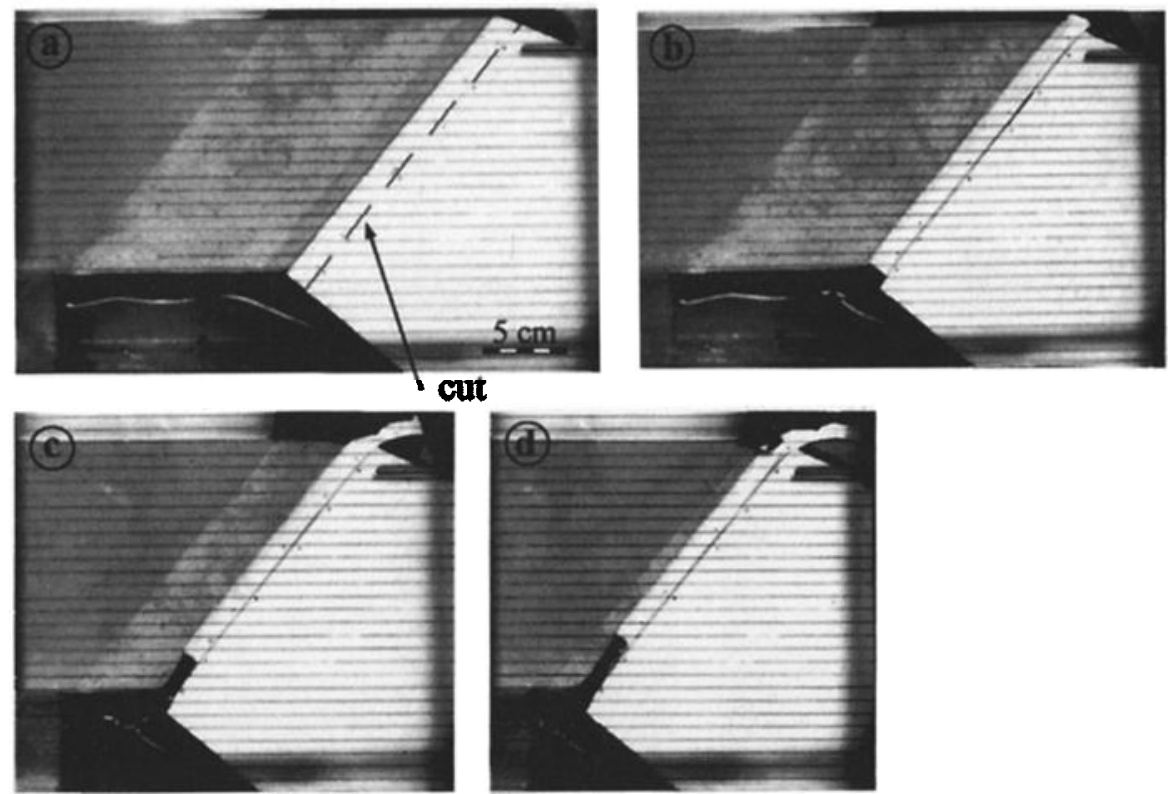

Figure 6. Experiment 5: view from above of fore experimental stages. High friction, dense subducting plate, the overriding plate is vertically cut in the forearc area (see Tables 1 and 2).

which is the interplate pressure (Figure 10). At low $\tau_{\mathrm{n}}$, this is $P_{\mathrm{n}}$ which controls the subduction regime or the stress state of the overriding lithosphere [Shemenda, 1993]. The regime can be either extensional or compressional. In the compressional regime the overriding plate undergoes a compression during subduction and the extensional regime is characterized by tension in the overriding plate (Figure 10b).

The $\tau_{\mathrm{n}}$ is a deviatoric stress by definition. It is also convenient to introduce a deviatoric or more exactly nonhydrostatic interplate pressure $\sigma_{\mathrm{n}}=P_{\mathrm{n}}-P_{\mathrm{h}}$ and nonhydrostatic pressure force $F_{\mathrm{p}}$
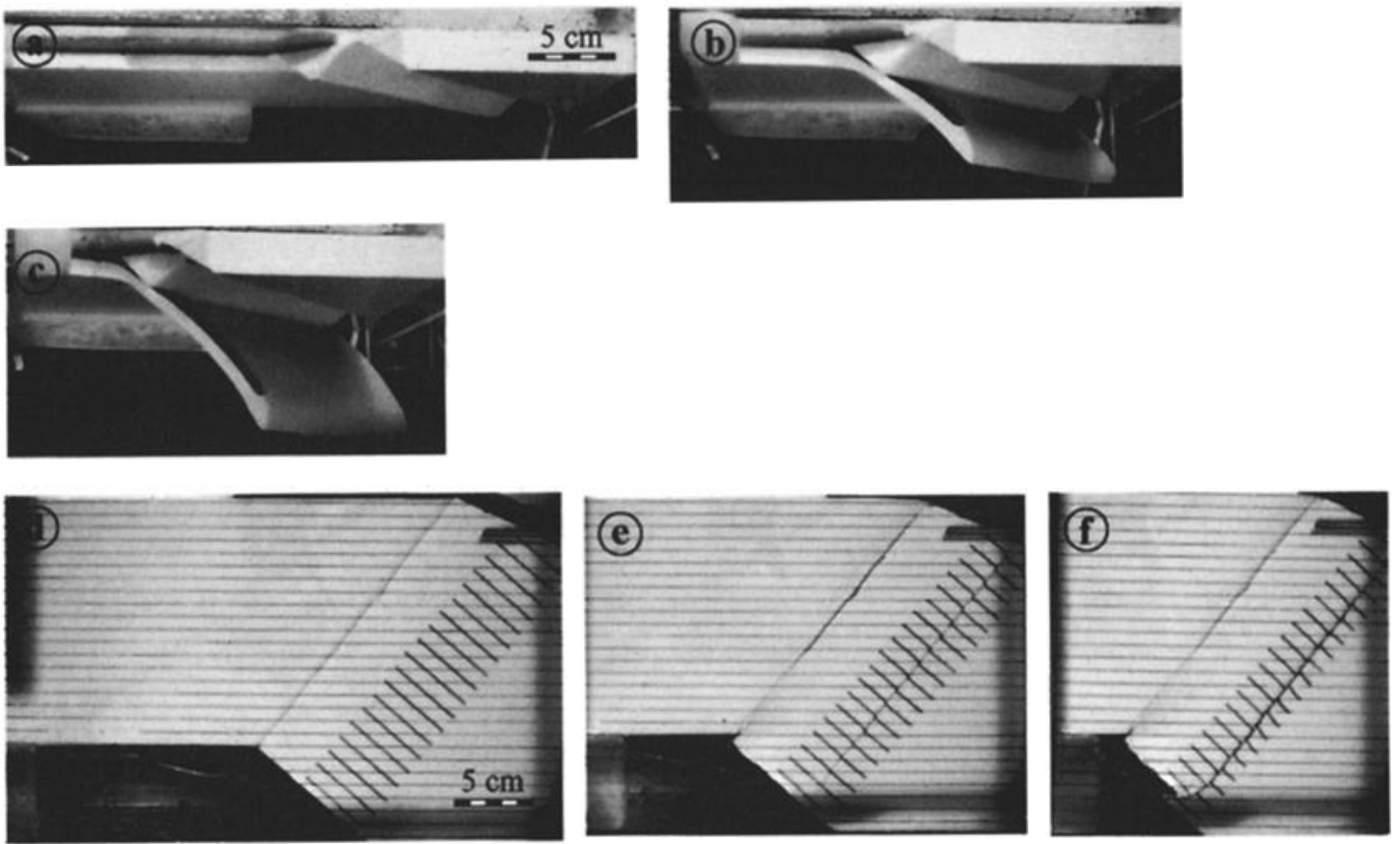

Figure 7. Experiment 6: (a) to (c) View from the side and (d) to (f), view from above. Friction is low, densities of the subducting plate and the asthenosphere are equal, and the overriding plate is thinned in the arc area (see Tables 1 and 2). 

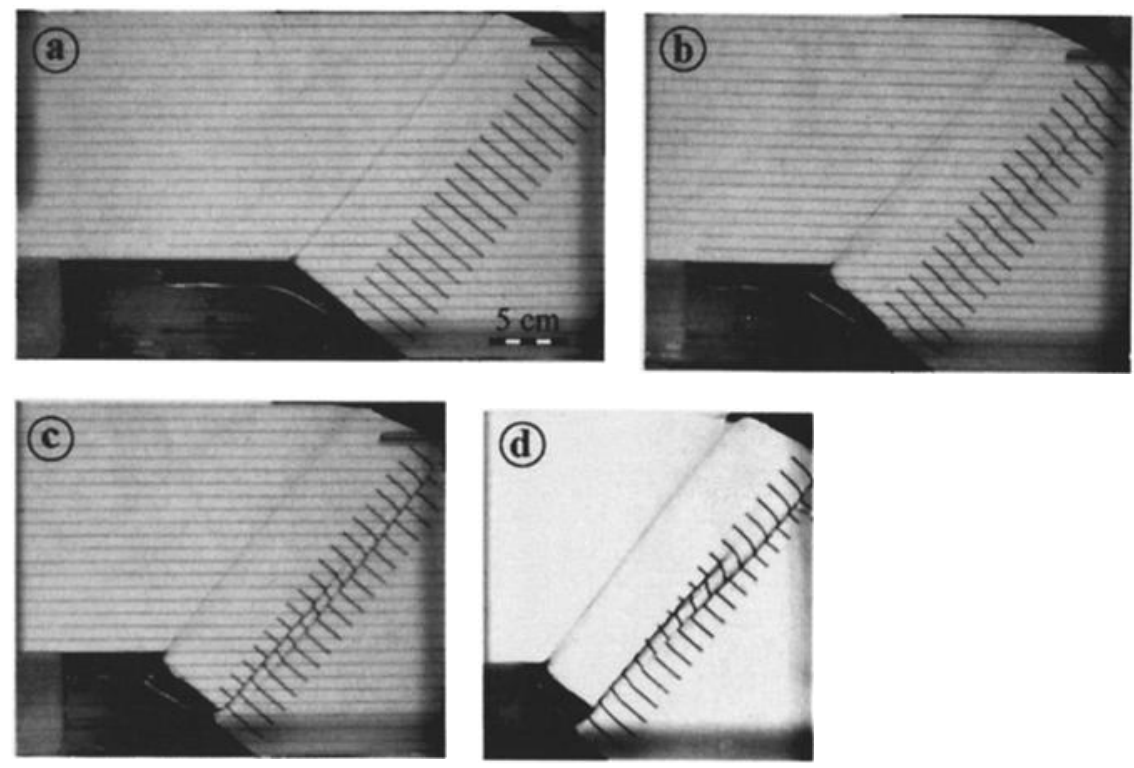

Figure 8. Experiment 7: view from above. Friction is low, densities of the subducting plate and the asthenosphere are equal, and the overriding plate is thinned in the arc area (see Tables 1 and 2).

caused by this pressure $\left(P_{h}=-p_{1} g z\right.$ is the hydrostatic pressure, and $z$ is detined in Figure 10a). The horizontal component of $F_{p}$ is (Figure 10)

$$
F_{\mathrm{P}_{\mathrm{h}}}=\int_{0}^{H} \sigma_{\mathrm{n}} d z,
$$

where $H$ is the thickness of overriding wedge. Considering this force, (5) can be rewritten

$$
F_{\mathrm{h}}=F_{\mathrm{fh}}+F_{\mathrm{ph}}
$$

$F_{\mathrm{Ph}}$ can be either compressive (negative) or extensional (positive) depending on the $\sigma_{\mathfrak{n}}$ value. The vertical component of the pressure force $F_{\mathrm{p}_{\mathrm{y}}}$ is oriented upward or downward, respectively (Figure 10). This force component produces either nonisostatic uplift (Figure 10a) or subsidence (Figure 10b) of the forearc area. The nonisostatic relief formed in this way generates high free-air gravity anomalies $\Delta \boldsymbol{g}$. The subduction regime thus can be related to the gravity anomalies [Shemenda, 1985, 1993, 1994]; The compressional regime is characterized by high positive gravity anomalies in the forearc and the extensional regime by negative

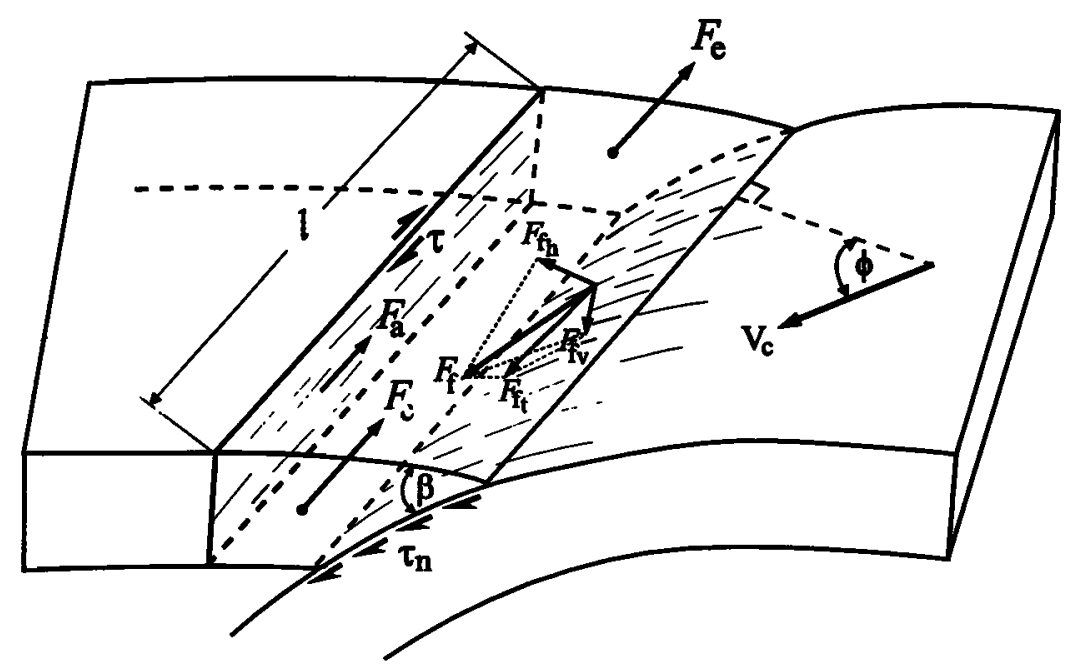

Figure 9. Forces in an oblique subduction zone. $V_{c}$ is the convergence velocity; $\phi$ is the obliquity angle; $\beta$ is the average subduction angle; $\tau_{n}$ is the interplate friction stress; $F_{f}$ is the interplate friction force per unit length of the plate boundary; $F_{\mathrm{fv}}, F_{\mathrm{f}}$, and $F_{\mathrm{fh}}$ are the vertical, trench-parallel, and horizontal (normal to the trench) components of the friction force, respectively; $l$ is the length of the considered segment of oblique plate boundary (of the forearc/arc sliver); $F_{\mathrm{c}}$ and $F_{\mathrm{e}}$ are the compressive and the extensional forces, respectively, acting at the transverse borders of the segment (sliver); $\tau$ is the tangential stress along the strike-slip fault; and $F_{\mathrm{a}}$ is the force caused by this stress resisting the strike-slip displacement of the sliver. 

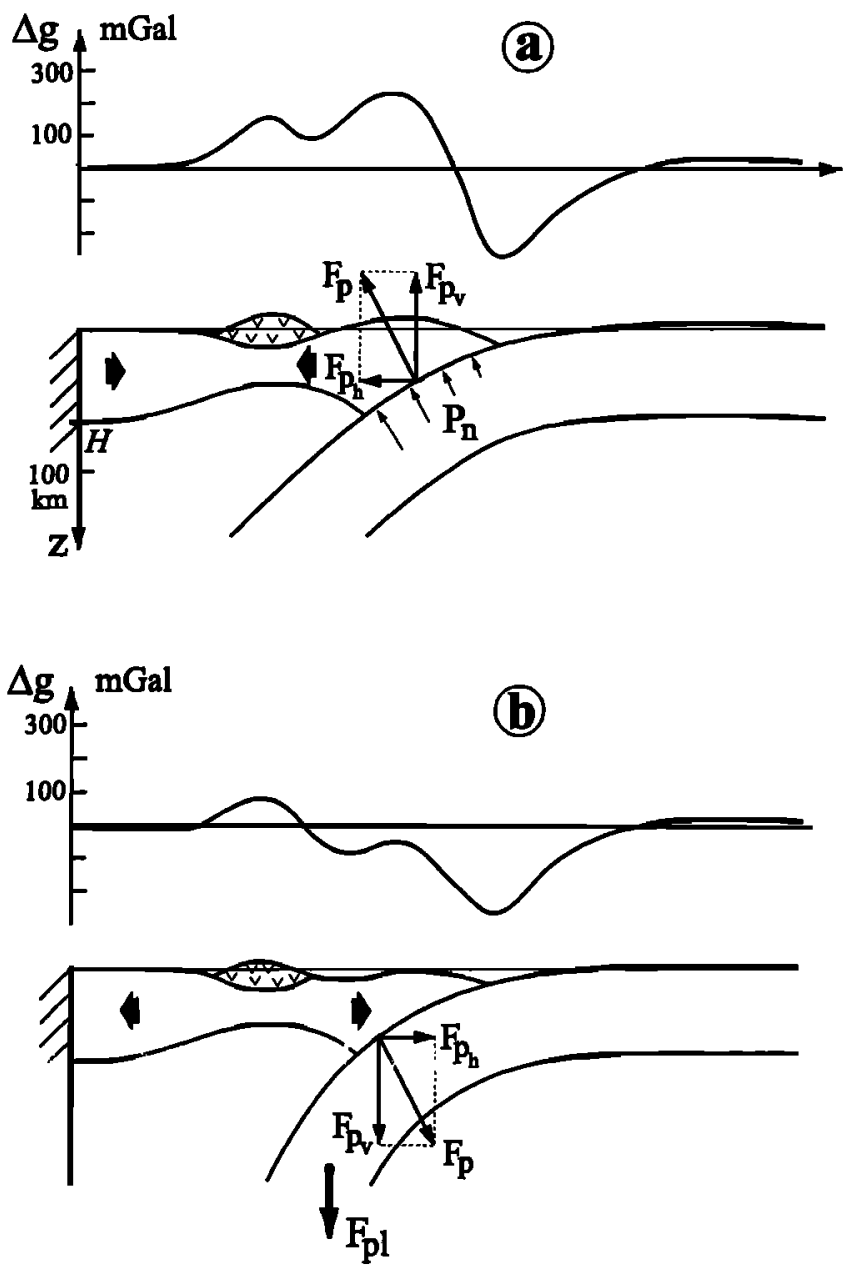

Figure 10. Two regimes of oceanic subduction [Shemenda, 1994]. (a) Compressional regime corresponding in the experiments to $\Delta \rho=\rho_{l}-\rho_{a}=0$ ( $\rho_{l}$ is the subducting lithosphere density, $\rho_{a}$ is the asthenospheric density). (b) Extensional regime corresponding to $\Delta \rho>0$ (see text for details). $\Delta g$ is the free-air gravity anomaly; $P_{\mathrm{n}}$ is the interplate pressure; $F_{\mathrm{p}}$ is the nonhydrostatic pressure force caused by nonhydrostatic interplate pressure $P_{\mathrm{n}}$ $P_{\mathrm{h}}\left(P_{\mathrm{h}}\right.$ is the hydrostatic pressure); $F_{\mathrm{P}_{\mathrm{v}}}$ and $F_{\mathrm{Ph}_{\mathrm{h}}}$ are the vertical and horizontal components of this force, respectively; $F_{\mathrm{pl}}$ is the pull force due to the positive density contrast $\Delta \rho$; and $H$ is the thickness of the overriding plate.

or small positive anomalies (Figure 10). Of course, $\Delta g$ in subduction zone is not only defined by the lithospheric deformation. The isostatic relief component also affects the gravity field but much less than the nonisostatic component. For example, $100 \mathrm{~m}$ of short-wavelength $(-100 \mathrm{~km})$ underwater isostatic relief generates $\sim 60$ times lower free-air gravity anomaly than the same nonisostatic relief. Gravity signature of $1-\mathrm{km}$ isostatic relief is almost 10 times smaller than of the same nonisostatic relief [Tang et al., 1999]. $\Delta g$ depends also on the gravity etfect of the subducted slab and the mantle dynamics. Both, however, are characterized by a small contribution to $\Delta g$ amplitude and a large wavelength. For example, the anomaly caused by the subducted slab has $\sim 1000-\mathrm{km}$ wavelength and a few tens $\mathrm{mGal}$ (or less) magnitude [Watts and Talwani, 1975]. We are dealing with $-100-\mathrm{km}$ wavelength anomalies with several tens to more than $100 \mathrm{mGal}$ amplitude (Figure 10). Therefore in 2-D approximation the absolute $\Delta g$ value in the fore arc is roughly proportional to the horizontal stress in the overriding lithosphere. For example, if in the extensional regime the overriding plate fails completely (back arc spreading is started), then this plate cannot maintain the extensive stress anymore and it can even undergo a compression due to the back arc ridge push force. Thus the presence of back arc spreading does not necessarily mean that the arc plate is under horizontal extensive force and hence that the interplate pressure should be small. If the interplate pressure is not reduced compared to the hydrostatic pressure, then there will be no nonisostatic displacement in the forearc and hence no associated gravity anomaly It shtuld be noted that tr a elation between the gravity anomalies and the suress in the lichosphere becomes mure complex in zones of continental subduction where low-density continental crust of variable thickness subducts to great depth [Tang et al., 1999].

In the experiments the nonhydrostatic interplate pressure $\sigma_{\mathrm{n}}$ is controlled by the density contrast $\Delta p=\rho_{l}-\rho_{a}$ and the length of the subducted plate, but in nature it depends on other factors as well, such as the direction of asthenospheric currents, and the direction of motion of the overriding plate in the "absolute" reference frame (relative horizontal motion of the subducted lithosphere and the surrounding mantle) [see Shemenda, 1993; and references herein]. If $\Delta \rho>0, F_{\mathrm{Ph}_{\mathrm{h}}}$ is zero or positive (extensional regime). This is the case in experiments $1,2,3$, and 5 . In experiment 2 the friction is low, and therefore the pressure force $F_{\mathrm{p}}$ completely defines the stress state of the overriding plate: This plate is under tension, but the tensional stress is not sufficient to fail a 5-mm-thick (in the thinned zone) overriding plate. This plate fails if it is thinned to about $3 \mathrm{~mm}$ which results in back arc opening (see experimental results reported by Shemenda [1993, 1994]). In experiments 1,3 and 5 the pressure force is the same as in experiment 2 , but the friction force is added. The horizontal component of this force $F_{\mathrm{h}}$ completely suppresses the horizontal component of the pressure force $F_{\mathrm{Ph}}$. The overriding plate therefore fails in experiment 1 (Figure 3 ) mainly under the alongtrench component of the friction force $F_{\mathrm{f}_{\mathrm{t}}}$ (there is some compression as well). This component then causes the slip partitioning.

If $\Delta p \leq 0, F_{\mathrm{Ph}_{h}}$ is negative. The subduction regime is always compressional whatever the interplate friction is. This regime is realized in experiments 4,6 , and 7 . In experiments 6 and 7 the friction is zero; therefore the stress state of the overriding plate is completely defined by the interplate pressure force. The horizontal component of this force $F_{\mathrm{Ph}}$ is sufficient to fail a 5-mm-thick overriding plate (see Figures 7 and 8 ), but there is no partitioning because the friction force is low. High-friction force in the compressional (experiment 4) as well as in the extensional (experiments 1 and 5) subduction regimes results in the partitioning. Experiment 7 (Figure 8) shows also that the overriding plate can fail along either of two opposite directions. According to 2-D experimental [Chemenda et al., 1997] and numerical [Tang et al., 1997] modeling the direction of failure is defined by two parameters, the distance $L$ between the trench and the failure location (the arc), and the interplate friction stress $\tau_{\mathrm{n}}$. If $\tau_{\mathrm{n}}$ is zero (the case of experiments 6 and 7) and $L$ is more than some critical value, the fault dips landward, and if less, it dips in the opposite direction, trenchward. The mechanism for "switching" the mode of failure with variation of $L$ and $\tau_{n}$ is associated with the flexural rigidity of the overriding plate and the wavelength of its bending. The critical $L$ value was estimated to be $\sim 200 \mathrm{~km}$ [Chemenda et al., 1997; Tang et al., 1997] which corresponds to the average trench-arc distance in the subduction zones. This value was as- 
sumed to calculate $L$ for the models presented above $(L=6 \mathrm{~cm}$ see Figure $2 \mathrm{a}$ ). Therefore both failure directions are possible under conditions of experiments 6 and 7 . In fact, these details of plate failure are probably not very important for the phenomenon of partitioning in reality, since the volcanic arc is characterized not only by thinned lithosphere [Zhao et al., 1994] but also by the presence of magma channels. In other words, this lithosphere " is already very weak [Sant Blanquat et al., 1998] and partly cut along subvertical surfaces connecting magma conduits filled with hot (molten) material which provides low friction. Such a situation corresponds best to experiments 3 to 5 with the vertical lubricated cut where partitioning occurs without thrusting. The lithosphere in the arc is thicker in these experiments than in the others and horizontal compressive force $F_{h}$ (see equation (7)) is not sufticient to cause it to fail. According to (4) partitioning should occur in this situation even if interplate friction is low. In reality there are two other forces $F_{\mathrm{c}}$ and $F_{\mathrm{e}}$ (see equation (3)) resisting the partitioning. It is these forces along with the subduction obliquity and the complete interplate friction force (equal to $F_{\mathrm{f}} \times l$, see Figure 9) which should control the lithospheric-scale strain partitioning.

To test the above analysis, we have chosen two comparatively simple examples: the southern Kurile and the southern Ryukyu subduction zones characterized by compressional and extensional regimes, respectively; one with clearly expressed lithosphericscale strain partitioning and another without it.

\subsection{Southern Kurile Arc}

This zone is characterized by high positive free-air gravity anomaly $\Delta g$ which reaches a maximum of more than $+250 \mathrm{mGal}$ in the frontal arc along the Lesser Kurile Islands and their underwater continuation, the Vityaz Ridge (Figure 11). The Kurile volcanic arc with much higher topography is marked by $\Delta g$ less than $+200 \mathrm{mGal}$ [Sandwell and Smith, 1997]. Hence the subduction regime in this zone is compressional (see Figure 10a). According to the NUVEL-1 model [DeMets et al., 1990], the subduction obliquity in the southern Kurile zone is not very high, $27^{\circ}$ (Figure 11). Despite that, slip partitioning exists in this region and has been nicely documented by Kimura $[1981,1986]$. The $\sim 800-\mathrm{km}$ long and $200-\mathrm{km}$-wide forearc sliver is moving to southwest at the rate of 6 to $11 \mathrm{~mm} / \mathrm{yr}$ [DeMets, 1992] which yields $p_{\mathrm{k}}=0.22$ \pm 0.07 ( $p_{\mathrm{k}}$ changes with time, and this estimate is very approximate). The northeastern sliver boundary corresponds to the Bussol Strait which is described as a graben. The southwestern termination of the sliver corresponds to the wide zone of southwest vergent thrusting within Hokkaido Island (Figure 11). The northwestern border of the sliver corresponds to a transcurrent fault which passes along the volcanic arc [Kimura, 1986]. The boundary conditions for the sliver are thus kinematically selfconsistent. The interplate friction force in this area should be very high and sufficient not only to overcome the resistance along the

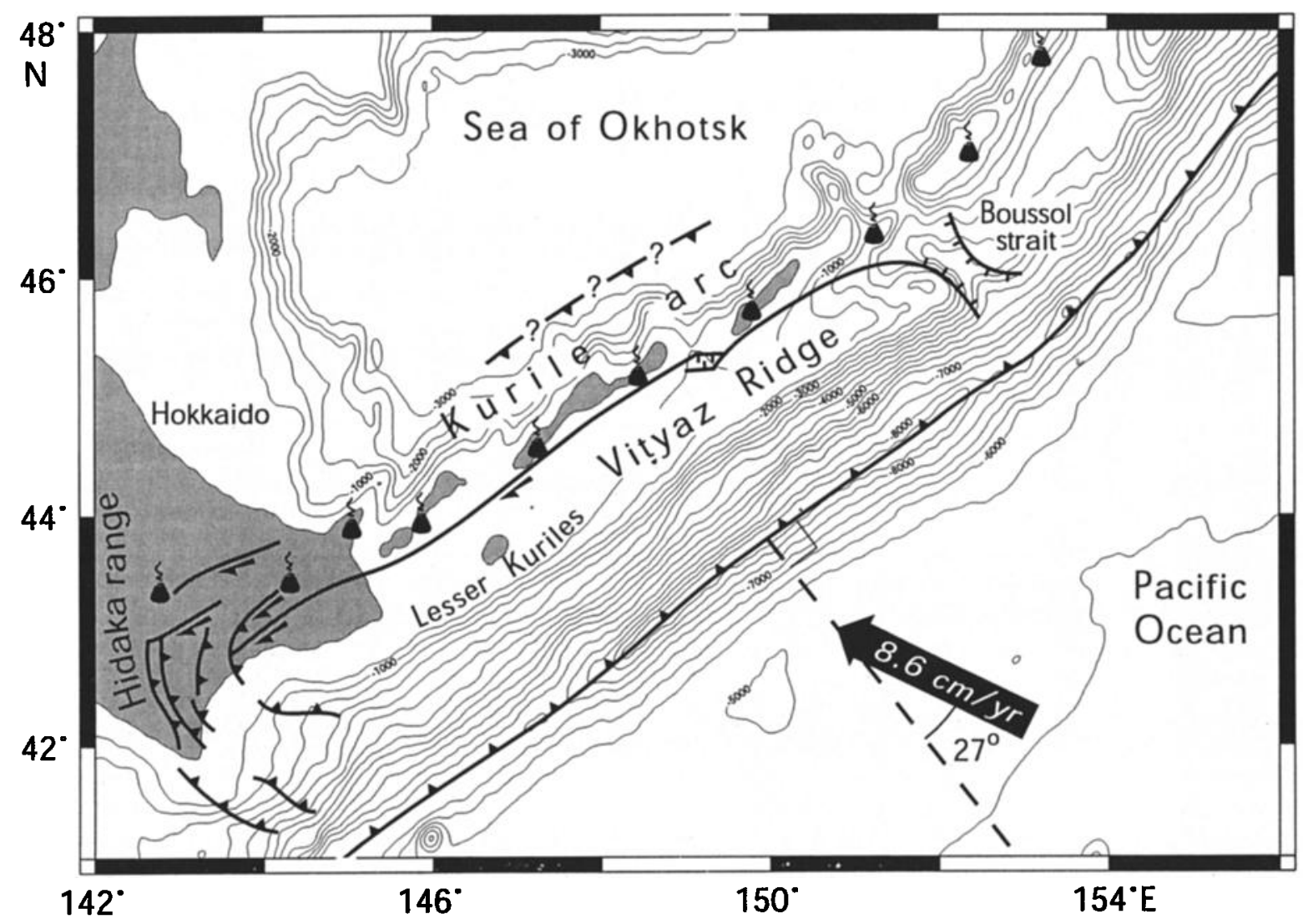

Figure 11. Geodynamic setting of the southwestern Kurile arc. Faults are from Kimura [1986], relative convergence vector from DeMets [1992]. The backthrust position is based on the structural and seismicity data from $B a$ ranov and Lobkovsky [1980], Savostin et al. [1983], and DeMets [1992]. 


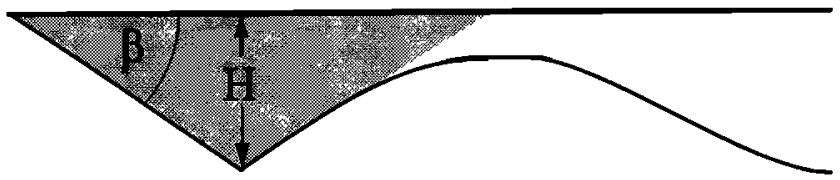

Figure 12. Scheme for the estimation of the cross-sectional surface of the forearc sliver.

strike-slip fault but also to cause the forearc block to fail in two places, at southern and northern ends of the sliver. Let us make an estimation of the friction force, staying within the simple rheologic model used in the present modeling. Assuming the thickness of the overriding wedge $H=60 \mathrm{~km}$, its average strength $\sigma_{s}=2 \times 10^{8} \mathrm{~Pa}$, the average subduction angle $\beta=30^{\circ}$, the obliquity angle $\phi=27^{\circ}$. and the length of the sliver $l=800 \mathrm{~km}$, we obtain (see Figure 12) $F_{\mathrm{c}}=F_{\mathrm{e}}=\sigma_{\mathrm{s}} H^{2} \cot \beta=1.24 \times 10^{1 \mathrm{R}} \mathrm{N}$. From (3) we have

$$
F_{\mathrm{f}_{\mathrm{t}}}=2 F_{\mathrm{c}}+F_{\mathrm{a}} .
$$

For simplicity, let us neglect the friction force $F_{\text {a }}$ along the volcanic arc. In this case the horizontal component of the friction force perpendicular to the trench will be (see equation (2))

$$
F_{\mathrm{fh}}=-F_{\mathrm{ft}} \cot \phi \cos \beta=-5.26 \times 10^{12} \mathrm{~Pa} \mathrm{~m}
$$

The corresponding friction stress is $\tau_{\mathrm{n}}=50 \mathrm{MPa}$, which is in agreement with heat data-based estimates of this parameter in compressional Japan subduction zone: $75 \pm 20 \mathrm{MPa}$ [Molnar and England, 1990] and 16-31 MPa [Tichelaar and Ruff, 1993]. The maximal value for the horizontal component of the pressure force $F_{\mathrm{Ph}}$ which characterizes the compressional regime of oceanic subduction at $\Delta \rho=0$ is defined by Shemenda [1994] to be around $-4 \times 10^{12} \mathrm{~Pa} \mathrm{~m}$ based on the previous modeling. A similar value $\left(3.6 \times 10^{12} \mathrm{~Pa} \mathrm{~m}\right.$ ) follows from experiments 6 and 7 presented in this paper. The total horizontal compressive force per unit length according to (7) thus is $F_{\mathrm{h}}=-9.26 \times 10^{12} \mathrm{~Pa} \mathrm{~m}$, i.e.. of the order of $10^{13} \mathrm{~Pa} \mathrm{~m}$. In the experiments corresponding to this case (highpressure force and high-friction force) the overriding plate fails along the thrust even if it is $>1 \mathrm{~cm}$ (but $<1.5 \mathrm{~cm}$ ) thick in the arc. Such a failure seems to be occurring in the Kurile arc as shown in Figure 13. It has been proposed that the active thrust fault behind the Kurile arc (Figure 11) corresponds to an incipient subduction zone [Baranov and Lobkovsky, 1980]. However, there is no strike-slip displacement along this fault. Such a displacement occurs directly along the arc which thus corresponds to the forearc sliver border. Hence there are two major faults in this area: the thrust fault behind the arc which accommodates part of the normal component of the plate convergence, and the strike-slip fault along the arc, which accommodates a shear displacement (Figure 13).

The obtained value of the interplate friction force for the $\mathrm{Ku}$ rile arc (see equation (9)) corresponds rather to the minimal estimation of this parameter as we neglected the resistance along the transcurrent fault. Therefore the $F_{\mathbb{f}_{\mathrm{h}}}$ value cari be still highoi Knowledge of the exact $F_{\mathrm{f}}$ value is not very important for the compressional subduction regime because both forces $F_{\mathrm{fh}}$ and $F_{\mathrm{Ph}_{\mathrm{h}}}$ are compressive, but it becomes very important for the extensional regime where $F_{\mathrm{Ph}}$ is extensional. It was found in previous modeling [Shemenda, 1993] that the maximal value of $\left|F_{\mathrm{Ph}}\right|$ in this case is comparable to, but less than, that for the compressional regime $\left(<3 \times 10^{12} \mathrm{~Pa} \mathrm{~m}\right)$. Therefore the interplate friction force estimated for the Kurile zone (9) would completely suppress the extensional force $F_{\mathrm{Ph}}$ if it would exist. The interplate friction stress in the extensional Mariana subduction zone is estimated to be $\tau_{\mathrm{n}} \approx 18 \pm 8 \mathrm{MPa}$ based both on the mineralogical/heat data [Maekawa et al., 1993] and the force balance analysis [Bird, 1978]. The corresponding horizontal compressive force is $F_{f_{h}}=(1.5-2.7) \times 10^{12} \mathrm{~Pa} \mathrm{~m}$ which is less than the extensional suction force $F_{\mathrm{Ph}}$ indicated above; the back arc extension is therefore possible in the Mariana zone. The situation when the interplate friction force completely suppresses the extensional force $F_{\mathrm{Ph}}$ corresponds to the late stages of experiments 1 and 3 where the overriding plate is characterized by neutral/slightly compressional stress state. To enable the back arc rifting, the friction should be lower. Reduction of the friction in the Kurile zone would stop the partitioning. In other words, a subduction zone geometrically similar to the Kurile arc but where the overriding plate is under tension should be characterized by lower

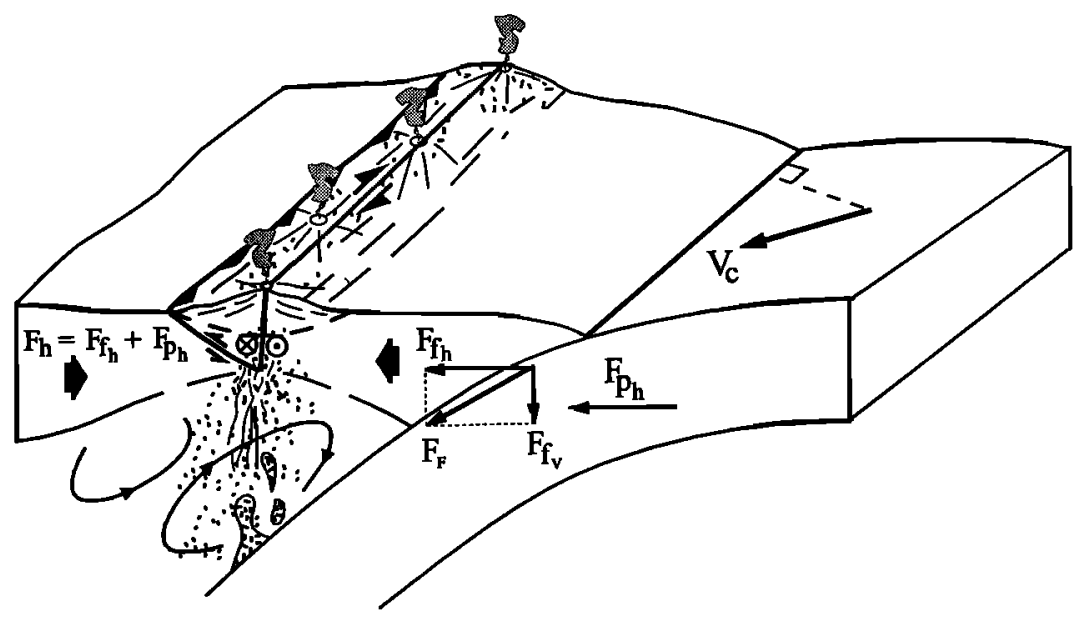

Figure 13. Compressional subduction regime and high interplate friction in an oblique subduction zone. The overriding plate fails along the thrust fault dipping under the arc from the rear). The partitioning occurs along the arc axis. $F_{\mathrm{F}}$ is the component of the friction force $F_{\mathrm{f}}$ (shown in Figure 9 ) parallel to the interplate surface and normal to the trench (see text for details). 
interplate friction and hence by the absence of the lithosphericscale partitioning. A good example of such a subduction zone could be the southern Ryukyu arc, which we consider below. Relative to the southem Kurile arc, this zone has comparable length $l$, average subduction obliquity $\phi$, and similar geometrical setting, suggesting similar "resistive" conditions at the transverse boundaries of the possible forearc sliver.

\subsection{Southern Ryukyu}

The positive anomaly $\Delta g$ in the Ryukyu arc is very low, less than $+80 \mathrm{mGal}$ and in the forearc area has a high negative value less than $-200 \mathrm{mGal}$ [Sandwell and Smith, 1997]. The model predicts thus that overriding plate is under high tensional stress [Shemenda, 1994], which is supported by the available geological and geophysical data [Letouzey and Kimura. 1986; Sibuet et al. 1995]. According to Seno et al. [1993] the obliquity of the convergence at southern termination of the Ryukyus is $\phi \approx 50^{\circ}$ (Figure 14), but recent GPS data [Imanishi et al., 1996] provide a smaller value, around $40^{\circ}$ [Lallemand and Lui, 1998]. The obliquity decreases to the northeast and reaches near $20^{\circ}$ at a distance of $l=800 \mathrm{~km}$ from Taiwan. The average obliquity of this segment is between $25^{\circ}$ and $30^{\circ}$. The geometric and kinematic setting thus is roughly similar to those in the Kurile zone. GPS measurements indicate a displacement of the Ryukyu arc southeastwards with respect to Asia at a rate of a few centimeters per year [Imanishi et al., 1996], instead of southwestward, which should be the case if lithospheric-scale slip partitioning would occur. Detailed swath mapping of the region [Sibuet et al., 1995; Lallemand et al., 1997, 1999] did not reveal any indication of transcurrent faulting neither in the Ryukyu arc nor in the Okinawa Trough. Trancurrent faulting is observed only within the accretionary prism. No E-W shortening has been detected at the western edge of the Ryukyu Arc near Taiwan; this shortening would exist if strain partitioning were present. On the contrary, GPS data even reveal some E-W extension in this area [ $\mathrm{Yu}$ et al., 1997]. Summarizing the above information, we conclude that there is no lithospheric-scale partitioning in the southern Ryukyu arc, which is consistent with our prediction: the interplate friction in the Ryukyu zone is much lower than in the Kurile zone (is near $10 \mathrm{MPa}$ ), which enables back arc rifting but "inhibits" strain partitioning.

\section{Conclusions}

The interaction between the plates in subduction zone is defined by normal (pressure) $P_{\mathrm{n}}$ and tangential (frictional) stresses along the interplate surface. Shemenda [1985] has shown that if

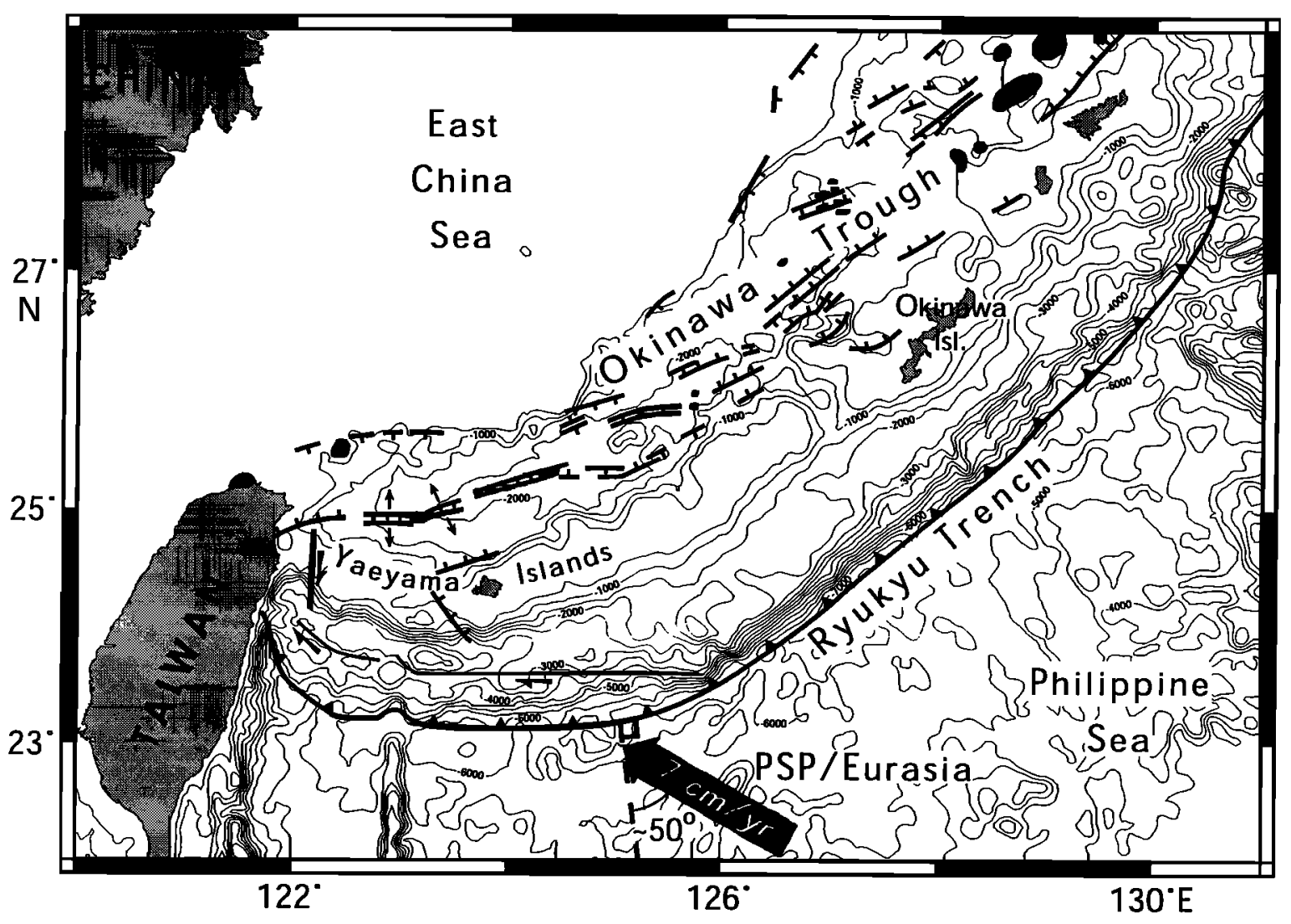

Figure 14. Geodynamic setting of the southwestem Ryukyu arc. The positions of the faults near Taiwan Lallemand et al. [1999]. The thin divergent arrows in the southern Okinawa Trough indicate the azimuth of opening based on GPS data [Imanishi et al., 1996]. The solid arrow on the Philippine Sea Plate indicates the mean direction of relative motion between this plate and Eurasia [after Seno et al. 1993]. Normal faults and black patches (presentday arc volcanism) are from Sibuet et al. [1987]. 
$P_{\mathfrak{n}}$ is higher on average than the hydrostatic pressure $P_{\mathrm{h}}$, the subduction regime is compressional (the overriding plate is under compression); if $P_{\mathrm{n}}<P_{\mathrm{h}}$, the regime is extensional. The frictional stress $\tau_{\mathbf{n}}$ and resulting friction force also contribute to the stress state of the overriding plate and can either increase the compression of the overriding plate in the compressional regime or reduce/eliminate the extension if the regime is extensional. The modeling shows that the strain partitioning associated with oblique subduction normally is possible only if the interplate friction is high because the partitioning is driven by the friction force. As high friction (friction force) can easily suppress the extension of the overriding plate caused by low $P_{\mathrm{n}}$, friction should be low in the subduction zones with back arc extension. This leads one to suppose that the interplate friction is pressuredependent; high friction corresponds to high pressure, both correspond to high coupling between the plates and vice versa. Such a dependence is well known for the rocks internal friction (Coulomb criterion), but it is not obvious for the friction between the plates in subduction zones. The latter probably has another nature and is controlled by the lubricating effect of very weak sediments dragged between the plates, the presence and dynamics of the fluids (water), the mineralogical transformations of material within the interplate zone, etc. [Molnar and England, 1990; Maekawa et al., 1993; Tichelaar and Ruff, 1993; Cloos and Shreve, 1996; Peacock, 1996]. The interplate friction seems to depend also on the roughness of the subducting seafloor [Lallemand et al., 1994].

$F_{\mathrm{f}_{\mathrm{t}}}$ thus should be small in extensional subduction zones. However, partitioning can still occur in these zones if the total along-trench friction force $F_{\mathrm{t}}=l \times F_{\mathrm{f}_{\mathrm{f}}}$ ( $l$ is the length of the oblique subduction zone) driving the partitioning is larger than the force $\left(l \times F_{\mathrm{a}}+F_{\mathrm{c}}+F_{\mathrm{e}}\right.$ ) resisting the partitioning (see equation (3)). On the other hand, oblique subduction and high $F_{t}$ value are not the only factors that make partitioning possible. Another necessary factor is weakness of the overriding plate. Partitioning occurs along zones of weakness which could be a preexistent fault (Sumatra), a volcanic line (Philippines, Sumatra, Kurile zones), or the axis of an active back arc basin (Andaman, Commander). It seems that in the geometrically simple situations the preferable place to fail (to accommodate a strike-slip displacement) is the volcanic arc where the resistance to shear is the lowest due probably to the presence of hot and weak material in magma channels and chambers (see Figure 13). Along with friction force, the forearc sliver can be driven by the lateral push or traction force corresponding to the forces $F_{\mathrm{c}}$ and $F_{\mathrm{e}}$ in Figure 9 but oriented in the opposite direction. An example could be the Hikurangi forearc sliver which is possibly driven (pulled) to the south due to the oblique collision in South Island resulting from subduction of the Chatham Rise and the Challenger Plateau.

\section{Notation}

$\sigma_{s} \quad$ yield limit of the lithosphere under normal load.

$\tau_{\mathrm{n}} \quad$ interplate friction stress.

$P_{\mathrm{n}} \quad$ interplate normal stress (pressure).

$P_{\mathrm{h}} \quad$ hydrostatic pressure.

$\sigma_{\mathrm{n}} \quad$ nonhydrostatic interplate pressure, defined as $P_{\mathrm{n}}-P_{\mathrm{h}}$.

$H \quad$ lithosphere thickness.

$l \quad$ length of the subduction zone segment with oblique convergence.

$L$ distance from the trench to the arc axis. $h$ thickness of the model lithosphere in the arc.

$\rho_{l} \quad$ density of the subducting lithosphere.

$\rho_{\mathrm{a}} \quad$ density of the asthenosphere.

$\Delta \rho \quad$ density contrast, defined as $\rho_{l}-\rho_{a}$

$V_{\mathrm{c}} \quad$ convergence velocity.

$V_{p} \quad$ velocity of the slip motion along the transcurrent fault.

$t$ time.

$\phi \quad$ subduction obliquity angle.

$\beta \quad$ subduction angle.

$\gamma \quad$ angle between interplate seismic slip velocity vector $V_{s}$ and the convergence velocity vector $V_{c}$.

$p_{\mathbf{k}} \quad$ kinematic criteria for the strain partitioning degree, defined as $V_{\mathrm{p}} / V_{\mathrm{c}} \sin \phi$.

$p_{\mathrm{s}} \quad$ seismic slip criteria for the strain partitioning degree, defined as $1-(\phi-\gamma) / \phi$.

$F_{\mathrm{f}} \quad$ interplate friction force per unit length of subduction zone.

$F_{\mathrm{f}_{\mathrm{t}}} \quad$ along-trench component of $F_{\mathrm{f}}$.

$F_{\mathrm{fh}} \quad$ horizontal component of $F_{\mathrm{f}}$.

$F_{\mathrm{f}} \quad$ vertical component of $F_{\mathrm{f}}$.

$F_{\mathrm{F}} \quad$ component of $F_{\mathrm{f}}$ parallel to the interplate surface and normal to the trench.

$F_{\mathrm{p}} \quad$ nonhydrostatic interplate pressure force per unit length of subduction zone.

$F_{\mathrm{P}_{\mathrm{v}}} \quad$ vertical component of $F_{\mathrm{p}}$.

$F_{\mathrm{p}_{\mathrm{h}}} \quad$ horizontal component of $F_{\mathrm{p}}$.

$F_{\mathrm{h}} \quad$ horizontal force, defined as $F_{\mathrm{ph}_{\mathrm{h}}}+F_{\mathrm{fh}}$.

$F_{\mathrm{a}} \quad$ friction force per unit length of the subduction zone along the transcurrent fault.

$F_{\mathrm{c}} \quad$ compressional force exerting at the transversal boundary of the mobile forearc sliver.

$F_{\mathrm{e}} \quad$ tension force exerting at the opposite transversal boundary of the mobile forearc sliver.

Fpl pull force.

Acknowledgments. We thank J.-Y. Collot, K. McClay, and M. Hamburger for critical reviews and A. Lomax for assistance with the English. This is a Géosciences Azur contribution \#275.

\section{References}

Baranov, B.V., and L.I. Lobkovsky, Shallow seismicity behind the Kurile Arc and its relation to the Benioff zone, Dokl. Akad. Nauk SSSR, 255, 67-71, 1980.

Baranov, B.V., N.I. Seliverstov, A.V. Muravlev, and E.L. Muzurov, The Komandorsky Basin as a product of spreading behind a transform plate boundary, Tectonophysics, 199, 237-269, 1991.

Barnes, P.M., and B. Mercier de Lepinay, Rates and mechanics of rapid frontal accretion along the very obliquely convergent southern Hikurangi margin, New Zealand, J. Geophys. Res., 102, 24,931-24,952, 1997.

Beck, M.E., Jr., On the mechanism of tectonic transport in zones of oblique subduction, Tectonophysics, 93, 1-11, 1983.

Beck, M.E., Jr., Coastwise transport reconsidered: lateral displacements in oblique subduction zones and tectonic consequences, Phys. Earth Planet. Inter., 68, 1-8, 1991.

Bevis, M., F.-W. Taylor, B.E. Schutz, J. Recy, B.L. Isaks, S. Helu, R. Singh, E. Kendrick, J. Stowell, B. Taylor, and B. Calmant, Geodetic observations of very rapid convergence and back-arc extension at the Tonga Arc. Nature, 374, 249-251, 1995.

Bird, P., Stress and temperature in subduction shear zones: Tonga and Mariana. Geophys. J. R. Astron. Soc., 55, 411-434, 1978. 
Braun, J., and C. Beaumont, Three-dimensional numerical experiments of strain partitioning at oblique plate boundaries: Implications for contrasting tectonic styles in the southem Coast ranges, California, and central South Island, New Zealand, J. Geophys. Res., 100, 18,059$18,074,1995$.

Burbidge, D. R., and J. Braun, Analogue models of obliquely convergent continental plate boundaries, $J$. Geophys. Res., I03, 15,221-15,237, 1998.

Chernenda, A.I., R. K. Yang, C.-H. Hsieh, and A.L. Groholsky, Evolutionary model for the Taiwan collision based on physical modeling, Tectonophysics, 274, 253-274, 1997.

Cloos, M., and R.L. Shreve, Shear-zone thickness and seismicity of Chilean- and Mariana-type subduction zones, Geology, 24, 107-110, 1996.

Collot, J.-Y., and B. Davy, Forearc structures and tectonic regimes at the oblique subduction zone between the Hikurangi Plateau and the southern Kermadec margin, J. Geophys. Res., 103, 623-650, 1998.

Curray, J.R., D.G. Moore, L.A. Lawver, F.J. Emmel, R.W. Raitt, M. Henry, and R. Kieckhefer, Tectonics of the Andaman Sea and Burma, in Geological and Geophysical Investigations of Continental Margins, edited by J.S. Watkins, L. Montadert, and P. Dickerson, AAPG, Mem., 29, 189-198, 1979.

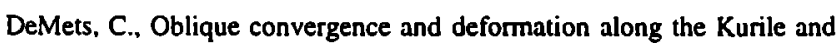
Japan trenches, J. Geophys. Res., 97, 17,615-17,625, 1992.

DeMets, C., R.G. Gordon, D.F. Argus, and S. Stein, Current plate motions, Geophys. J. Int., 101, 425-478, 1990.

Diament, M., H. Harjona, K. Karta, C. Depuis, D. Dahrin, M.T. Zen, M. Gerard, O. Lassal, A. Martin, and J. Malod, Mentawai fault zone off Sumatra: A new key to the geodynamics of western Indonesia, Geology, 20, 259-262, 1992.

Fitch, T.J., Plate convergence, transcurrent faults, and internal deformation adjacent to southeast Asia and the western Pacific, J. Geophys. Res., 77, 4432-4460, 1972.

Furukawa, Y., Magmatic processes under arcs and formation of the volcanic front, J. Geophys. Res., 98, 8309-8319, 1993.

Imanishi, M., F. Kimata, N. Inamori, R. Miyajima, T. Okuda, K. Takai, and $\mathrm{K}$. Hirahara, Horizontal displacements by GPS measurements at the Okinawa-Sakishima Islands (1994-1995) (in Japanese), Earthquake, 2, 49, 417-421, 1996.

Jarrard, R. D., Terrain motion by strike-slip faulting of fore arc slivers, Geology, 14, 780-783, 1986a.

Jarrard, R. D., Relations among subduction parameters, Rev. Geophys., 24, 217-284, 1986b

Kimura, G., Tectonic evolution and stress field in the southwestem margin of the Kurile Arc, Geol. Soc. Jpn., 87, 757-768, 1981.

Kimura, G., Oblique subduction and collision: fore arc tectonics of the Kurile Arc, Geology, 14, 404-407, 1986.

Lallemand, S., La Subduction Océanique, 208 pp., Gordon and Breach, Newark, N.J., France, 1999.

Lallemand, S., and C.-S. Liu, Geodynamic implication of present-day kinematics in the southem Ryukyus, J. Geol. Soc. China, 41, 551$564,1998$.

Lallemand, S.E., P. Schurle, and J. Malavieille, Coulomb theory applied to accretionary and nonaccretionary wedges: Possible causes for tectonic erosion and/or frontal accretion, J. Geophys. Res., 99, 12,03312,055, 1994.

Lallemand, S., C.-S. Liu, and the ACT Scientific Crew, Swath bathymetry mapping reveals details of the active arc-continent collision offshore Taiwan, EOS Trans. AGU, 78, 173-175, 1997.

Lallemand, S., C.-S. Liu, S. Dominguez, P. Schnurle, J. Malavieille, and the ACT Scientific Crew, Trench-parallel stretching and folding of forearc basin and lateral migration of the accretionary wedge in the southem Ryukyus: $A$ case of strain partition caused by oblique convergence, Tectrmics, 18, $231-247,1999$.
Letouzey, J., and M. Kimura, The Okinawa Trough: Genesis of a backarc basin, developing along a continental margin, Tectonophysics, 125, 209-230, 1986.

Liu, X., K.C. McNally, and Z.-K. Shen, Evidence for a role of the downgoing slab in earthquake slip partitioning at oblique subduction zones, J. Geophys. Res., 100, 15,351-15,372, 1995.

Maekawa, H., M. Shozui, T. Ishii, P. Fryer, and J.A. Pearce, Blueshist metamorphism in an active subduction zone, Nature, $364,520-523$, 1993.

McCaffrey, R., Oblique plate convergence, slip vectors, and forearc deformation, J. Geophys. Res., 97, 8905-8915, 1992.

Molnar, P., and P.C. England, Temperatures, heat flux, and frictional stress near major thrust faults, J. Geophys. Res., 95, 4833-4856, 1990.

Peacock, S.M., Thermal and petrologic structure of subduction zones, in Subduction: Top to Bottom, Geophys. Monogr. Ser. vol.96, edited by G.E. Bebout et al., pp. 119-133, AGU, Washington, D.C., 1996.

Pinet, N., and P.R. Cobbold, Experimental insights into the partitioning of motion within zones of oblique subduction, Tectonophysics, 206, 371-388, 1992.

Platt, J.-P., Mechanics of oblique convergence, J. Geophys. Res., 98, 16,239-16,256, 1993.

Ryan, H.F., and P.J. Coleman, Composite transform-convergent plate boundaries: Description and discussion, Mar. Pet. Geol., 9, 89-87, 1992.

Ruff, L.J., Do trench sediments affect great earthquake occurrence in subduction zones?, Pure Appl. Geophys., 129, 263-282, 1989.

Sandwell, D.T., and W.H.F. Smith, Marine gravity anomaly from Geosat and ERS-1 satellite altimetry, J. Geophys. Res., 102, 10,039-10,054, 1997.

Sant Blanquat, M., B. Tikoff, C. Teyssier and J.L. Vigneresse, Transpressional kinematics and magmatic arcs, in Continental Transpressional and Transtensional Tectonics, edited by R. Holdsworth, R.E. Strachan, and R.A. Dewey, Geol. Soc. Spec. Publ., 135, 327-340, 1998.

Savostin, L., L.P. Zonenshain, and B. Baranov, Geology and plate tectonics of the Sea of Okhotsk, in Geodynamics of the western PacificIndonesian Region, Geodyn. Ser., vol. 11, edited by T.W.C. Hilde and S. Uyeda, pp. 189-222, AGU, Washington, D.C., 1983.

Schmidt, M., and S. Poli, Experimentally based water budgets for dehydrating slabs and consequences for arc magma generation, Earth Planet. Sci. Lett., I63, 361-379, 1998.

Seno, T., S. Stein, and A.E. Grip, A model for the motion of the Philippine Sea Plate consistent with NUVEL-1 and geologic data, J. Geophys. Res., 98, 17,941-17,948, 1993.

Shemenda, A.I., Modelıng of tne opening mechanism tor certain types ot back arc basins (in Russian), Oceanology, 25, 204-210, 1985.

Shemenda, A.I., Physical modeling of horizontal lithosphere compression and subduction, J. Geophys. Res., 97, 11,097-11,161, 1992.

Shemenda, A.I., Subduction of lithosphere and backarc dynamics: Insights from physical modeling, J. Geophys. Res., 98, 16,167-16,185, 1993.

Shemenda, A.I., Subduction: Insights From Physical Modeling, Ser. Mod. Approaches Geophys., vol. 11, 215 pp., Kluwer Acad., Norwell, Mass., 1994.

Sibuet, J.-C., J. Letouzey, F. Barbier, J. Charvet, J.-P. Foucher, T.W.C. Hilde, M. Kimura, C. Ling-Yun, and B. Marset, Back arc extension in the Okinawa Trough, J. Geophys. Res., 92, 14,041-14,063, 1987.

Sibuet, J.-C., S.-K. Hsu, C.-T. Shyu, and C.-S. Liu, Structural and kinematic evolution of the Okinawa trough backarc basin, in Backarc Basins: Tectonics and magmatisme, edited by B. Taylor, pp. 343-379, Plenum, New York, 1995.

Tang. J.-C., A. Chemenda, J. Chery, and S. Lalleinand. Combined physical and mathematical inodelling of arc-contınent collision (abstract). Terra Nova. 9. Abstr. Suppl. NI. 177. 1997. 
Tang, J.-C., A. Chemenda, and N. Bethoux, Numerical modelling of arccontinent collision: Application to Taiwan (abstract), J. Conf. Abstr., 4, 38, 1999.

Tichelaar, B.W., and L.J. Ruff, Depth of seismic coupling along subduction zones, J. Geophys. Res., 98, 2017-2037, 1993.

Turcotte, D.L., and G. Schubert, Geodynamics: Applications of Cantinuum Physics to Geological Problems, pp. 235-237, John W1ley, New York, 1982.

Uyeda, S., and H. Kanamori, Back arc opening and the mode of subduction, J. Geophys. Res., 84, 1049-1061, 1979.

Watts, A.B., and M.Talwani, Gravity effect of downgoing lithospheric slabs beneath island arcs, Geol. Soc. Am. Bull., 86, 1-4, 1975.

Wesnousky, S.G., and C.H. Jones, Oblique slip, slip partitioning, spatial and temporal changes in the regional stress field, and the relative strength of active faults in the Basin and Range, western United States, Geology, 22, 1031-1034, 1994.

Yu, G., S.G. Wesnousky, and G. Ekström, Slip partitioning along major convergent plate boundaries, Pure Appl. Geophys., 140, 183-210, 1993.
Yu, S.-B., H.-Y. Chen, and L.-C. Kuo, Velocity field of GPS stations in the Taiwan area, Tectonophysics, 274, 41-59, 1997.

Zhao, D., A. Hasegawa, and H. Kanamori, Deep structure of Japan subduction zone as derived from local, regional, and teleseismic events, $J$. Geophys. Res., 99, 22,313-22,329, 1994.

A. Bokun, Institute of Geology and Geochemistry of Fuel ivinierat, Lvov, Ukraine

A. Chemenda, Géosciences Azur, UMR 6526, Université de NiceSophia Antipolis, 250 Rue Albert Einstein-Sophia Antipolis, F-06560 Valbonne, France. (chem@ faille.unice.fr)

S. Lallemand, Laboratoire de Géophysique, Tectonique et Sedimentologie, UMR 5573, Université Montpellier II, Case 060, Pl. E. Bataillon, F-34095 Montpellier Cedex 05, France.

(lallem@dstu.univ-montp2.fr)

(Received September 28, 1999; revised August 13, 1999; accepted September 9, 1999.) 